\title{
Effect of Combining Maize Straw and Palm Oil Fuel Ashes in Concrete as Partial Cement Replacement in Compression
}

\author{
Samson Olalekan Odeyemi ${ }^{1, *}$, Rasheed Abdulwahab ${ }^{1}$, \\ Zainab Tolu Giwa ${ }^{1}$, Mukaila Abiola Anifowose ${ }^{2}$, \\ Omolola Titilayo Odeyemi ${ }^{3}$ and Chibuzo Frances Ezenweani ${ }^{1}$ \\ ${ }^{I}$ Department of Civil and Environmental Engineering, Kwara State University Malete, Nigeria \\ ${ }^{2}$ Department of Civil Engineering, Federal Polytechnic Offa, Kwara State, Nigeria \\ ${ }^{3}$ Department of Science Laboratory Technology, Kwara State Polytechnic, Ilorin, Kwara State, Nigeria
}

("Corresponding author's e-mail: samson.odeyemi@kwasu.edu.ng)

Received: 31 May 2020, Revised: 7 March 2021, Accepted: 10 March 2021

\begin{abstract}
The high energy consumption connected with cement manufacturing, as well as the depletion of limestone resources and the release of carbon dioxide, which contributes to global warming, are all important issues that must be addressed. Partially replacing cement with agricultural wastes in concrete, which reduces cement output, is an innovative solution to this problem. This paper examined the effect of combining Palm Oil Fuel Ash (POFA) and Maize Straw Ash (MSA) as partial replacement of cement on the compressive strength of Grade 20 concrete at $0-30 \%$ POFA and $0-30 \%$ MSA using Historical data under the Response Surface study in Design-Expert software. The concrete cubes were tested at 7,28, and 56 days of curing. It was discovered that there was a decrease in the compressive strength of the concrete with the percentage increase in the quantity of the POFA and MSA for all the curing days considered. However, there was a progressive increase in the compressive strength with an increase in the days of curing. The optimum combination of percentages of POFA, MSA and cement that gave a strength greater than the target compressive strength of $20 \mathrm{~N} / \mathrm{mm}^{2}$ in 56 days is $30 \%$ POFA and $16.6 \%$ MSA and $53.4 \%$ Cement at 0.58 water-cement ratio.
\end{abstract}

Keywords: Cement replacement, Concrete, Compressive strength, Maize straw ash, Palm oil fuel ash

\section{Introduction}

Concrete comprises of cement, coarse and fine aggregates with water to aid binding. Cement makes up about $10-15 \%$ of the total mass of concrete [1]. Production of cement not only involves high consumption of energy at high temperatures (roughly in the range of $1,500{ }^{\circ} \mathrm{C}$ ) but also produces poisonous gases among which includes $\mathrm{CO}_{2}, \mathrm{CH}_{4}$ and $\mathrm{NO}_{3}$ into the atmosphere [2] Efforts have been made to reduce raw materials consumption, ensure environmentally friendly operations and improve the quality of cement. To achieve this, consideration is being given for partial replacement for cement using waste materials such as maize straw and rice husk [3-6]. Research has shown that these agricultural wastes contain highly reactive silica which reacts with calcium hydroxide in concrete, resulting in compact concrete microstructure [7].

Due to the increase in population and industrialization, the production of waste materials and the extinction of natural sources have increased alongside the high demand for building materials [8]. High energy demand associated with the production of cement as well as the depletion of limestone deposits and emission of carbon dioxide which causes global warming are major problems which researchers strive to find solutions. These have resulted in the search for alternative materials to replace existing building materials. Hence, the rapid development of new technology in material science.

Globally, researchers have made significant contributions to identify potential applications of byproducts as a replacement to construction materials. Particularly, research has been geared towards improving the properties of cement and potential replacement of cement in concrete. Agricultural and industrial wastes possess pozzolanic properties conforming to the requirement in BS EN 197-1 [9] and have been studied and applied as partial replacements for cement [10]. According to Okwadha [11]; Ugwuanyi and Onuamah [12], the use of plant ashes such as those obtained from maize cob, sawdust, and 
sugarcane bagasse as cement replacement should be encouraged for use in concrete to reduce environmental degradation associated with the mining of cement manufacturing materials. This would also reduce the construction budget associated with the high cost of cement since blended concrete of higher strength can be made with longer curing periods [13].

Maize straw ash is the burnt residue of the leaves, stalks, and cobs of maize plants left on the field after harvest [14]. MSA possesses substantial pozzolanic properties and a large amount of silica [15]. However, only a few studies have been conducted on its use in concrete.

POFA is a by-product obtained from the burning of palm tree wastes such as palm kernel shells, palm oil fiber, and palm oil husk. They are commonly disposed of in open spaces triggering environmental pollution problems resulting in health hazards. Owing to its high pozzolanic properties and abundance, many studies have been conducted to evaluate its use in construction [16-17]. Pone et al. [18] reported that POFA performed well as a pozzolan in concrete just like Silica fume. They recommended its use up to $5 \%$ in concrete for precast and prestressed girders.

There has been no study on the effect of combining POFA and MSA in concrete. Hence, this work investigates the combination of POFA and Maize Straw Ash (MSA) as a suitable replacement for cement and its strength properties in concrete.

\section{Materials and methods}

The material used in this study was POFA, MSA, cement, aggregate (fine and coarse), and water. Ordinary Portland cement (Dangote cement brand) of grade $32.5 \mathrm{~N}$ with a specific gravity of 3.10, which conforms to NIS 444-1 [19], was used for this research. Coarse aggregate of $12.5 \mathrm{~mm}$ diameter and fine aggregate of sizes ranging from 0.1 to $1 \mathrm{~mm}$ diameter conforming to the requirement in BS EN 12620:2002+A1:2008 [20] was utilized. Potable water of pH 7 as recommended by Neville [21] and Odeyemi et al. [6] was used for the concrete mix. Samples of POFA and MSA used in the research after sieving are shown in Figure 1.

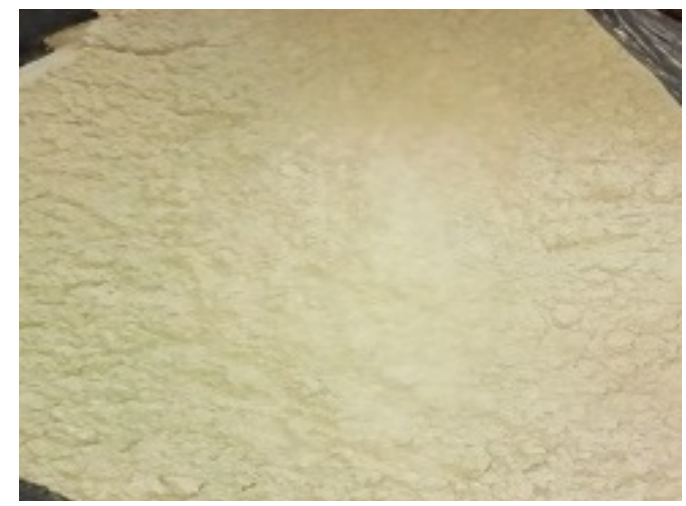

(a) POFA after sieving

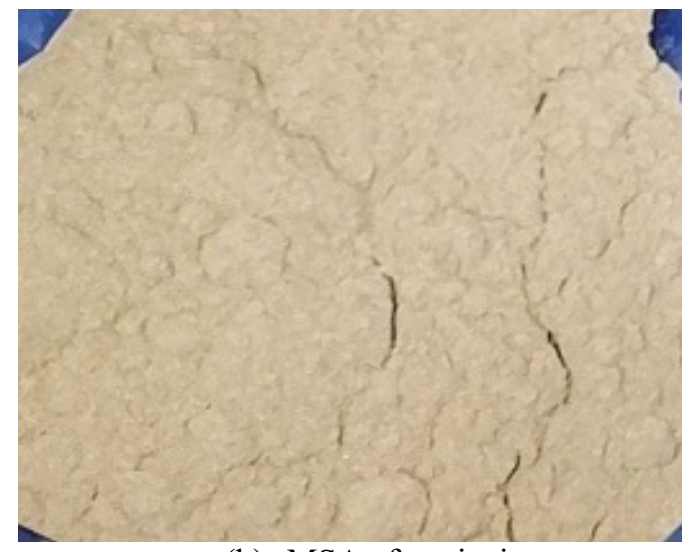

(b) MSA after sieving.

Figure 1 POFA and MSA after sieving. 
Particle size distribution of the fine aggregates utilized for this research was conducted as stipulated in BS EN 12620:2002+A1:2008 2008 [20] The percentage of the particles passing through the sieves (Table 1) was plotted against the particle diameters and presented in Figure 2. The fineness modulus for the fine aggregate was obtained from Eq. (1) while the uniformity coefficient, which reveals the grading of the aggregate, was calculated from the graph using Eq. (2);

Fineness modulus $=\frac{\text { Total cummulative percentage retained }}{100}$

$C_{u}=\frac{D_{60}}{D_{10}}$

where: $C_{u}$ is the Uniformity coefficient, $D_{60}$ represents the diameter of particles matching $60 \%$ fines passing through the sieves on the cumulative particle-size distribution curve while $D_{10}$ represents the diameter of particles matching $10 \%$ fines passing on the cumulative particle-size distribution curve. If the $C_{u}$ of the soil sample is less than 4.0 it can be deduced that the material sample is uniformly graded but if $C_{u}$ of the sample is greater than 4.0 the material is well graded [21-23].

Table 1 Sieve analysis details for fine aggregate.

\begin{tabular}{cccccc}
\hline $\begin{array}{c}\text { Diameter of sieve } \\
(\mathbf{m m})\end{array}$ & $\begin{array}{c}\text { Mass of Sieve } \\
(\mathbf{g})\end{array}$ & $\begin{array}{c}\text { Mass of Sieve \& Soil } \\
(\mathbf{g})\end{array}$ & $\begin{array}{c}\text { Soil Retained } \\
(\mathbf{g})\end{array}$ & $\begin{array}{c}\text { Soil Retained } \\
(\mathbf{\%})\end{array}$ & $\begin{array}{c}\text { Soil Passing } \\
(\%)\end{array}$ \\
\hline 1.000 & 340.11 & 453.69 & 113.58 & 22.7 & 77.3 \\
0.850 & 333.29 & 373.54 & 40.25 & 8.1 & 69.2 \\
0.600 & 313.52 & 436.44 & 122.92 & 24.6 & 44.7 \\
0.500 & 299.5 & 369.29 & 69.79 & 14.0 & 30.7 \\
0.300 & 278.79 & 386.57 & 107.78 & 21.6 & 9.1 \\
0.250 & 271.84 & 287.51 & 15.67 & 3.1 & 6.0 \\
0.180 & 269.78 & 289.79 & 20.01 & 4.0 & 2.0 \\
pan & 371.65 & 381.65 & 10 & 2.0 & 0.0 \\
\hline
\end{tabular}

POFA was gotten from the byproduct of palm trees. The fiber itself was gotten after oil had been extracted from the palm fruits for oil production. The fiber was then gathered and sun-dried. The ash (POFA) was gotten from the controlled burning of dried palm oil fibers at a temperature of $650{ }^{\circ} \mathrm{C}$ for $2 \mathrm{~h}$ as recommended by Mehmannavaz et al. [24] and Odeyemi et al. [6]. The ash was allowed to cool for a day and then sieved using a $90 \mu \mathrm{m}$ sieve. MSA was gotten from the remains of the maize plant after the maize has been harvested. The dry straws were uprooted, and the root cut off and then subject to controlled burning at $650{ }^{\circ} \mathrm{C}$ for $2 \mathrm{~h}$ as recommended by Mehmannavaz et al. [24] and Odeyemi et al. [6]. The ash was allowed to cool for a day and then sieved using a $90 \mu \mathrm{m}$ sieve. The POFA and MSA samples were examined in the laboratory for X-Ray Fluorescence (XRF) analysis to determine their chemical composition.

The absolute volume method as specified by BS EN 206:2013+A1:2016 [25], Neville [21] and Shetty [22] was adopted for the design mix with a characteristic of $20 \mathrm{~N} / \mathrm{mm}^{2}$. Concrete cubes of $100 \mathrm{~mm}$ by $100 \mathrm{~mm}$ by $100 \mathrm{~mm}$ were cast. The cubes were cured by immersion in water for 7, 28 and 56 days, respectively since concrete containing pozzolanic materials is known to gain strength slowly at the early days of curing [26-28]. The cubes were then crushed in batches to check for their compressive strength in accordance with BS EN 12390-3:2009 [29].

The experimental setup was designed using Design expert (version 10) software. It was used in designing the percentages at which POFA and MSA can be used to partially replace cement to achieve a concrete compressive strength of M20, using a range of $0-30 \%$ for both POFA and MSA. 


\section{Results and discussion}

\section{Chemical composition of ashes}

The XRF analysis was used to analyze the elemental composition of the samples. The method employed in the analysis was the energy-dispersive analysis (ED-XRF) and the machine model used to determine the basic chemical composition of POFA and MSA was the Shimadzu EDXRF-702HS. Tables $\mathbf{2}$ and $\mathbf{3}$ show the chemical compositions as well as loss of ignition of POFA and MSA, respectively.

Table 2 XRF result of POFA.

\begin{tabular}{cccc}
\hline $\mathbf{S} / \mathbf{N}$ & Parameters & Formulae & \% Composition \\
\hline 1 & Silicon Oxide & $\mathrm{SiO}_{2}$ & 60.62 \\
2 & Aluminum Oxide & $\mathrm{Al}_{2} \mathrm{O}_{3}$ & 3.59 \\
3 & Ferric Oxide & $\mathrm{Fe}_{2} \mathrm{O}_{3}$ & 3.69 \\
4 & Titanium Oxide & $\mathrm{TiO}_{2}$ & 0.73 \\
5 & Calcium Oxide & $\mathrm{CaO}$ & 7.28 \\
6 & Lead Oxide & $\mathrm{Pb}_{2} \mathrm{O}_{5}$ & 3.73 \\
7 & Magnesium Oxide & $\mathrm{MgO}$ & 3.24 \\
8 & Sulphite & $\mathrm{SO}_{3}$ & 1.96 \\
9 & Sodium Oxide & $\mathrm{Na}_{2} \mathrm{O}$ & 0.66 \\
10 & Potassium Oxide & $\mathrm{K}_{2} \mathrm{O}$ & 7.49 \\
11 & Manganese Oxide & $\mathrm{MnO}$ & 0.63 \\
12 & Nickel Oxide & $\mathrm{NiO}$ & 0.20 \\
13 & Chromium Oxide & $\mathrm{CuO}$ & 0.23 \\
14 & Copper Oxide & $\mathrm{LOI}$ & 1.37 \\
15 & Loss of Ignition & & 2.62
\end{tabular}

Table 3 XRF result of MSA.

\begin{tabular}{cccc}
\hline $\mathbf{S} / \mathbf{N}$ & Parameters & Formulae & \% Composition \\
\hline 1 & Silicon Oxide & $\mathrm{SiO}_{2}$ & 38.49 \\
2 & Aluminum Oxide & $\mathrm{Al}_{2} \mathrm{O}_{3}$ & 3.98 \\
3 & Ferric Oxide & $\mathrm{Fe}_{2} \mathrm{O}_{3}$ & 0.82 \\
4 & Titanium Oxide & $\mathrm{TiO}_{2}$ & 0.21 \\
5 & Calcium Oxide & $\mathrm{CaO}$ & 10.39 \\
6 & Lead Oxide & $\mathrm{Pb}_{2} \mathrm{O}_{5}$ & 0.24 \\
7 & Magnesium Oxide & $\mathrm{MgO}$ & 5.72 \\
8 & Sulphide & $\mathrm{SO}_{3}$ & 3.59 \\
9 & Sodium Oxide & $\mathrm{Na}_{2} \mathrm{O}$ & 0.09 \\
10 & Potassium Oxide & $\mathrm{K}_{2} \mathrm{O}$ & 22.46 \\
11 & Manganese Oxide & $\mathrm{MnO}^{2}$ & 2.07 \\
12 & Chromium Oxide & $\mathrm{Cr}_{2} \mathrm{O}_{3}$ & 0.04 \\
13 & Chloride & $\mathrm{Cl}^{-}$ & 3.48 \\
14 & Loss of Ignition & $\mathrm{LOI}^{2}$ & 6.60
\end{tabular}

The results from the XRF analysis show that both POFA and MSA have a percentage content of Silicon oxide $\left(\mathrm{SiO}_{2}\right)$ greater than $25 \%$. Both ashes also possess a high percentage content of Aluminum Oxide $\left(\mathrm{Al}_{2} \mathrm{O}_{3}\right)$, Ferric oxide $\left(\mathrm{Fe}_{2} \mathrm{O}_{3}\right)$ and Calcium oxide $(\mathrm{CaO})$ which are major compounds in cement. Based on these criteria, they are suitable as pozzolans in concrete [9]. However, POFA has a higher content of $\mathrm{SiO}_{2}(60.62 \%)$ than MSA $(38.49 \%)$.

\section{Particle size distribution}

The result of the particle size distribution for the fine aggregate is presented in Figure 2. The dimension of the aggregate range between 0.10 to $1 \mathrm{~mm}$ indicating that they fall within the category of fine and medium sand [21]. The aggregate's fineness modulus was obtained as 2.99. The fineness 
modulus for fine aggregates ranges from 2.3 - 3.1 [30]. This result is within the acceptable limit for fine aggregates. The $C_{u}=3$ means that the fine aggregate is uniformly graded.

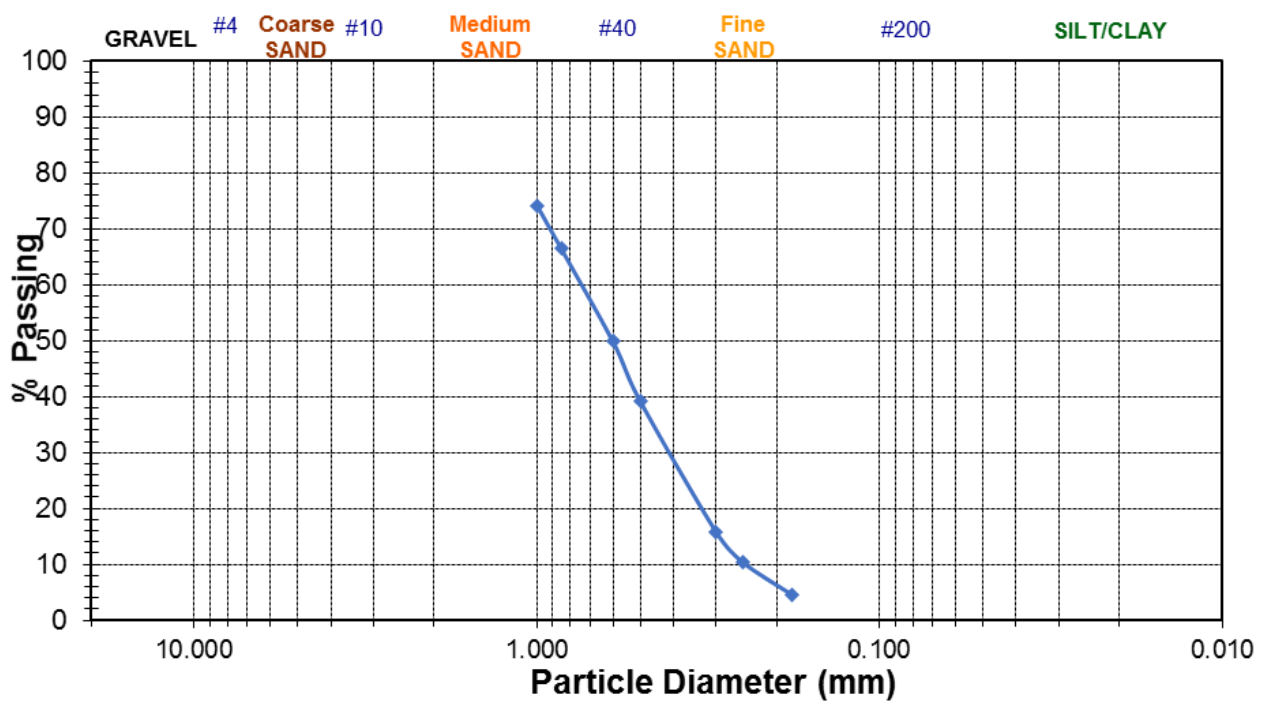

Figure 2 Particle Size distribution for Fine Aggregate.

\section{Results for compressive strength test of concrete}

The compressive strength of the cubes was gotten for 7, 28 and 56 days, respectively, the results (Tables 4 - 6) were analyzed using Historical data of the Response Surface study in Design Expert 10.0 software. The results obtained are shown in Tables 3, 4 and 5, respectively for 7, 28, and 56 days.

Table 4 Compressive strength result for 7 days.

\begin{tabular}{cccccc}
\hline S/N & w/c ratio & OPC $\%$ & POFA $\%$ & MSA $\%$ & COMPRESSIVE STRENGTH $\left(\mathbf{N} / \mathbf{m m}^{2}\right)$ \\
\hline 1 & 0.58 & 100 & 0 & 0 & 17.7 \\
2 & 0.58 & 70 & 30 & 0 & 6.5 \\
3 & 0.58 & 70 & 15 & 15 & 6.2 \\
4 & 0.58 & 40 & 30 & 30 & 5.3 \\
5 & 0.58 & 70 & 0 & 30 & 6.2 \\
6 & 0.58 & 70 & 22.5 & 7.5 & 7.2 \\
7 & 0.58 & 70 & 7.5 & 22.5 & 5.7 \\
\hline
\end{tabular}

Table 5 Compressive strength result for 28 days.

\begin{tabular}{cclccc}
\hline S/N & w/c ratio & OPC $\%$ & POFA $\%$ & MSA $\%$ & COMPRESSIVE STRENGTH $\left(\mathbf{N} / \mathbf{m m}^{2}\right)$ \\
\hline 1 & 0.58 & 100 & 0 & 0 & 25.5 \\
2 & 0.58 & 70 & 30 & 0 & 17.3 \\
3 & 0.58 & 70 & 15 & 15 & 9.5 \\
4 & 0.58 & 40 & 30 & 30 & 9.6 \\
5 & 0.58 & 70 & 0 & 30 & 10.3 \\
6 & 0.58 & 70 & 22.5 & 7.5 & 13.3 \\
7 & 0.58 & 70 & 7.5 & 22.5 & 11.4 \\
\hline
\end{tabular}


Table 6 Compressive strength result for 56 days.

\begin{tabular}{cccccc}
\hline S/N & w/c ratio & OPC $\%$ & POFA $\%$ & MSA $\%$ & COMPRESSIVE STRENGTH $\left(\mathbf{N} / \mathbf{m m}^{2}\right)$ \\
\hline 1 & 0.58 & 100 & 0 & 0 & 33.8 \\
2 & 0.58 & 70 & 30 & 0 & 20.4 \\
3 & 0.58 & 70 & 15 & 15 & 12.4 \\
4 & 0.58 & 40 & 30 & 30 & 13.7 \\
5 & 0.58 & 70 & 0 & 30 & 11.7 \\
6 & 0.58 & 70 & 22.5 & 7.5 & 16.3 \\
7 & 0.58 & 70 & 7.5 & 22.5 & 14.9 \\
\hline
\end{tabular}

\section{Compressive strength}

From Figures 3(a), 3(b) and 3(c), It was deduced that there was a decrease in the compressive strength of the concrete with the percentage increase in the quantity of the POFA and MSA for all the curing days considered. However, there was a progressive rise in compressive strength with advancement in the days of curing.
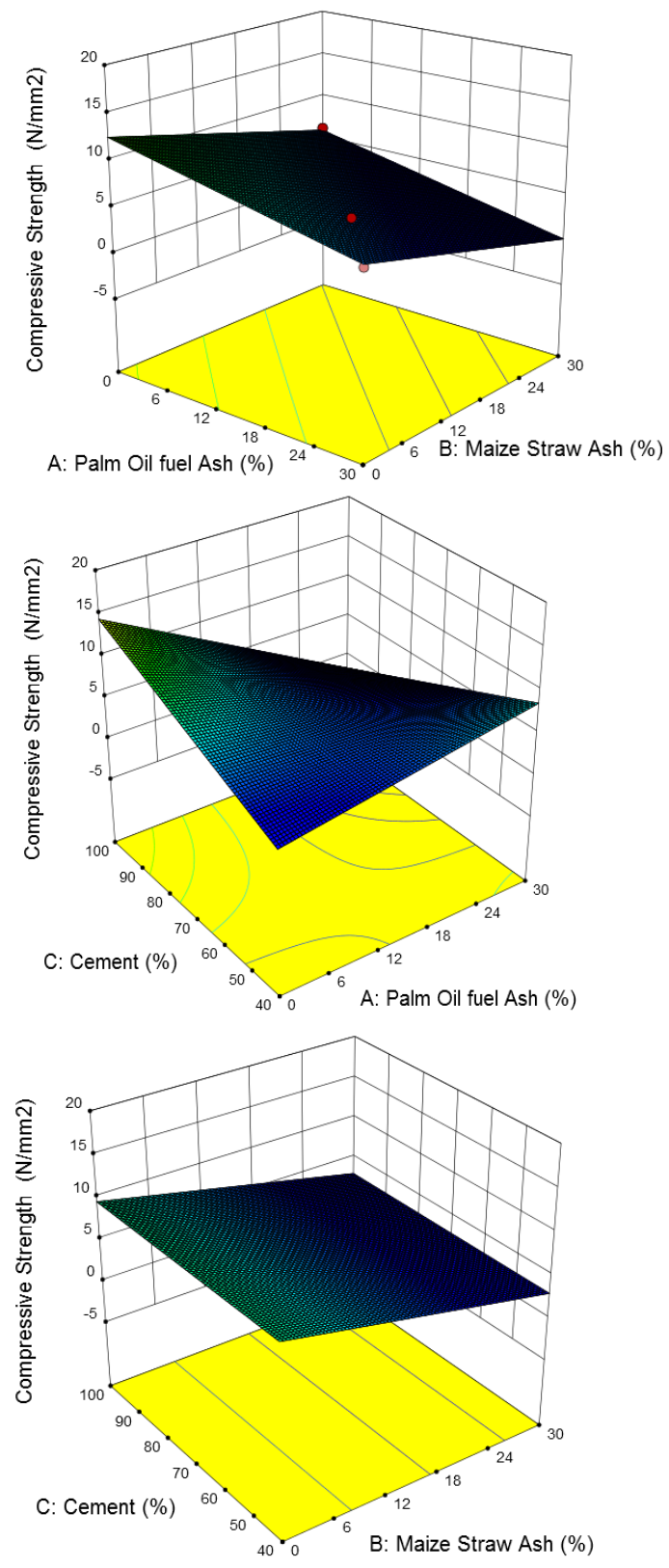

(a) Compressive strength at 7 days. 

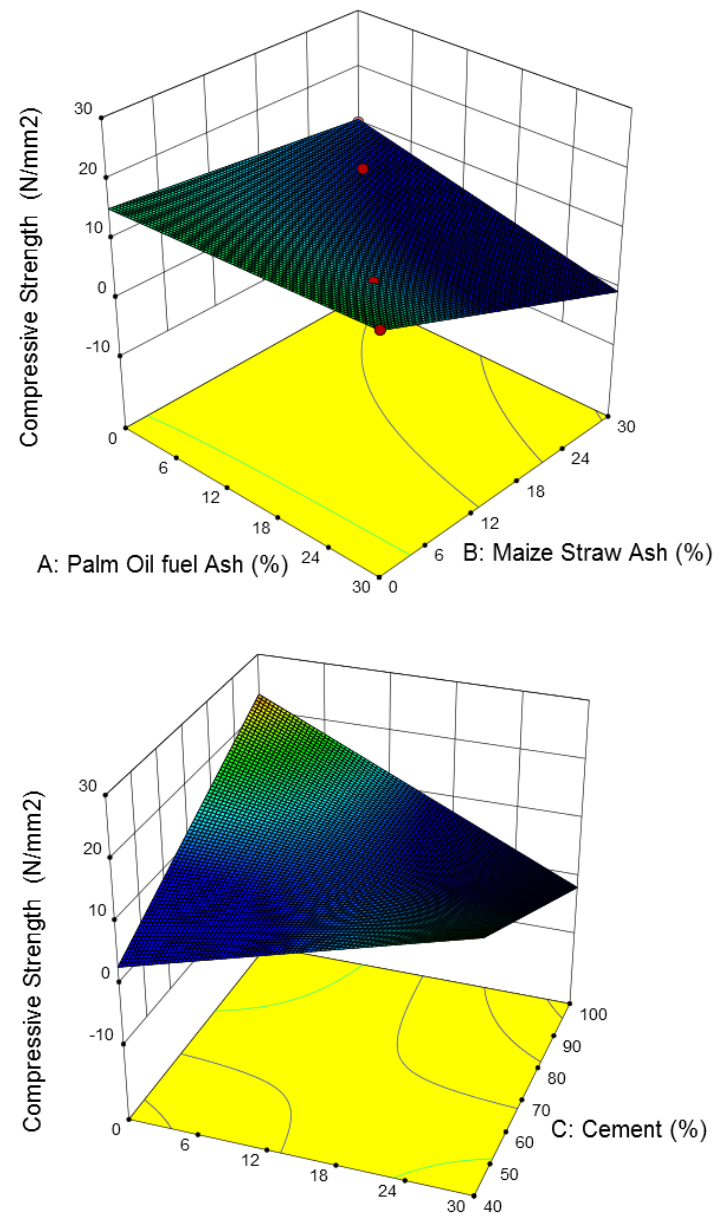

A: Palm Oil fuel Ash (\%)

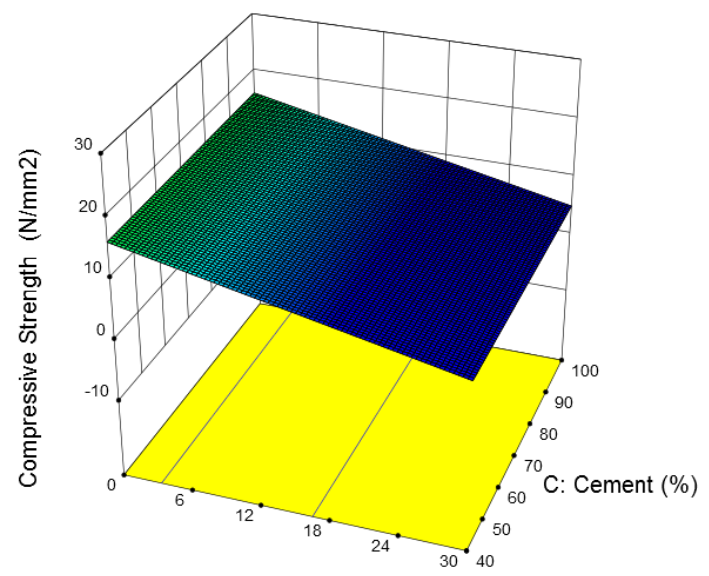

B: Maize Straw Ash (\%)

(b) Compressive strength at 28 days. 

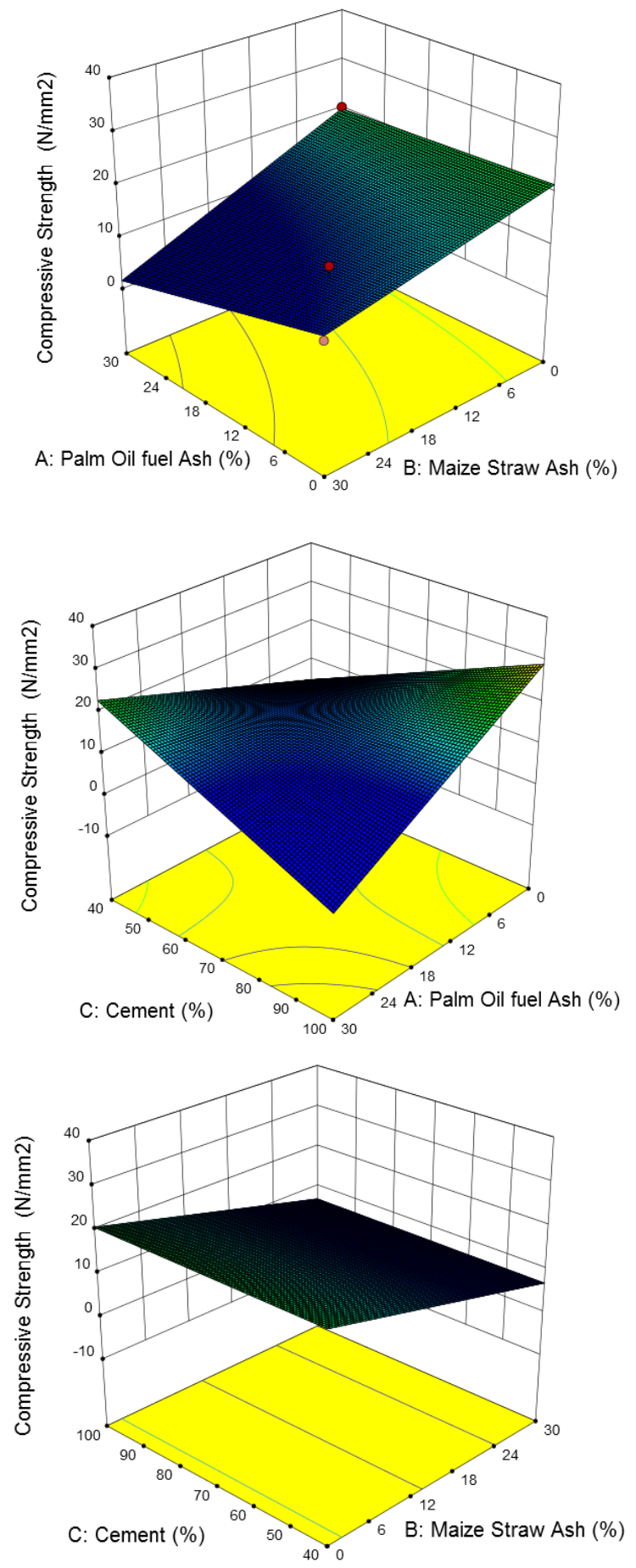

(c) Compressive Strength results at 56 days.

Figures 3 (a) - (c) Compressive strength result 7, 28 and 56 days.

\section{Optimization of materials}

In optimizing the material combinations, the objective was to maximize the compressive strength of the concrete and the percentages of POFA and MSA while the percentage of cement was minimized (i.e. increasing the quantity of the POFA and MSA in the concrete). It was discovered that the optimum 
combination of percentages of POFA and MSA that will give a compressive strength of $21.94 \mathrm{~N} / \mathrm{mm}^{2}$ in 56 days are $30.0 \%$ POFA, $16.6 \%$ MSA and $53.4 \%$ cement.

The Model that relates compressive strength to the percentage of POFA, MSA and Cement is given in Eq. (1). This model has a $p$-value of 0.0459 , indicating that it is significant;

Compressive Strength $=13.97-3.15 \mathrm{~A}-6.90 \mathrm{~B}-2.34 \mathrm{AB}-12.12 \mathrm{AC}$

where $\mathrm{A}=$ Percentage of POFA and $\mathrm{B}=$ Percentage of MSA and $\mathrm{C}=$ Percentage of Cement

This result has a combined desirability value of 0.712 as presented in Figure 4.
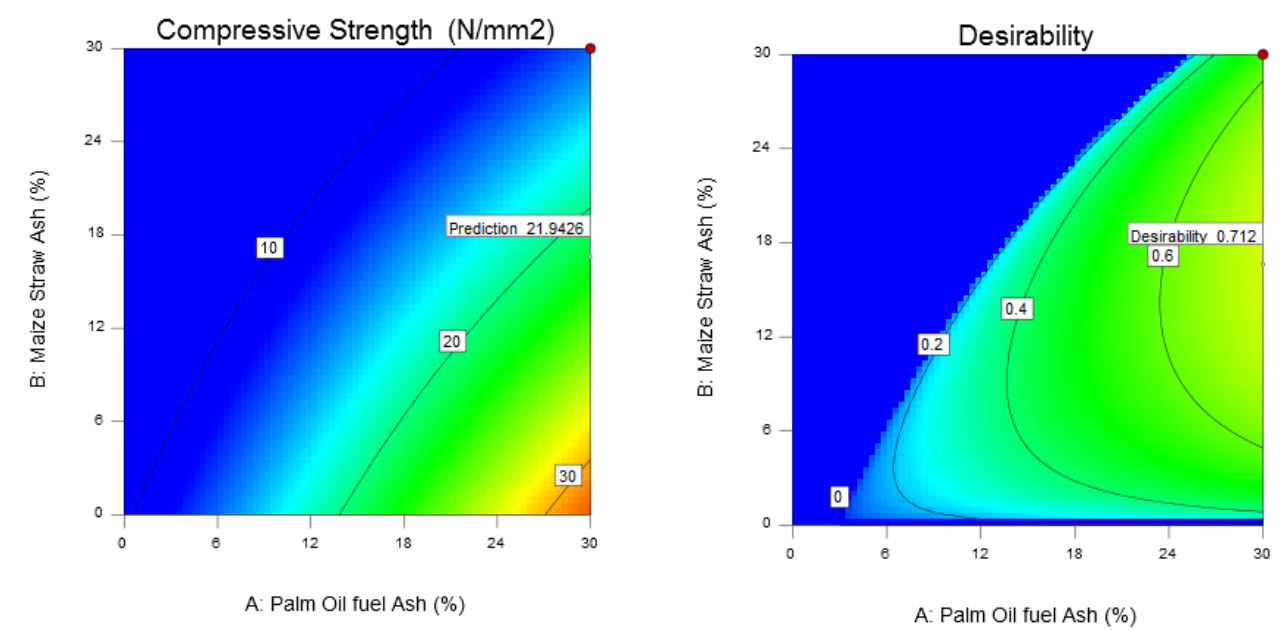

Figure 4 Desirability of the result.

\section{Validation of results}

The Predicted versus the Actual data for the compressive strength is shown in Figure 5. The figure reveals that both the predicted and actual data are close as shown by the linear graph. The colour range indicates the lower and upper boundaries of the compressive strengths of the concrete. The $\mathrm{R}^{2}$ value of 0.97 and an Adjusted $\mathrm{R}^{2}$ value of 0.93 also validate the results obtained. The Adequate Precision ratio of 12.37 is greater than 4 . This indicates that the model is adequate to navigate the design space $[3,31]$.

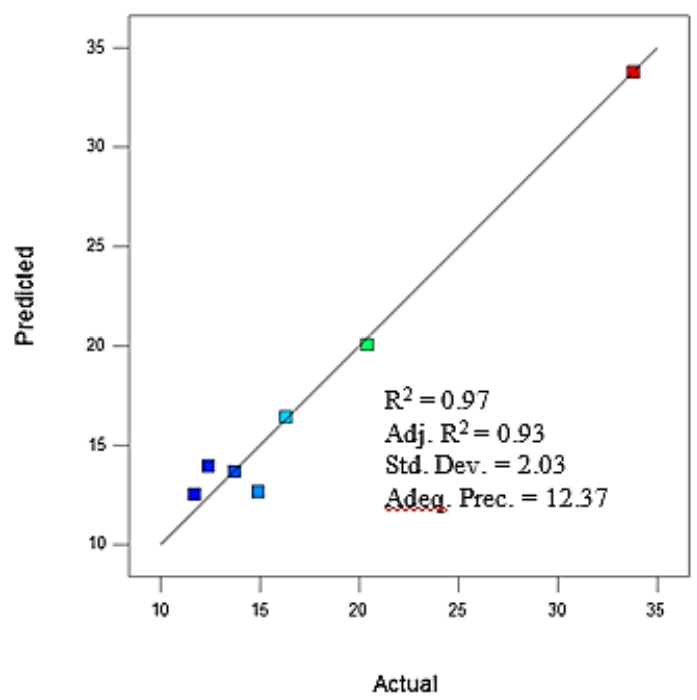

Figure 5 Predicted vs. Actual results. 


\section{Conclusions}

This investigation led to the following conclusions: Palm Oil Fuel Ash and Maize Straw Ash can be used to substitute cement in concrete to some extent. The best alternative for cement in Grade 20 concrete is $30 \%$ Palm Oil Fuel Ash and 16.6\% Maize Straw Ash.

\section{Acknowledgements}

The authors appreciate the contributions of the staff of the Department of Civil and Environmental Engineering, Kwara State University, Malete, Nigeria, for their contributions to this research.

\section{References}

[1] SO Odeyemi, OD Atoyebi and EK Ayo. Effect of guinea corn husk ash on the mechanical properties of lateritic concrete. IOP Conf. Ser. Earth Environ. Sci. 2020; 445, 1-11.

[2] N Cobîrzan, A Balog and E Moşonyi. Investigation of the natural pozzolans for usage in cement industry. Procedia Technology. In: Proceedings of the $8^{\text {th }}$ International Conference Interdisciplinarity in Engineering, Romania. 2015, p. 506-11.

[3] SO Odeyemi, R Abdulwahab, AG Adeniyi and OD Atoyebi. Physical and mechanical properties of cement-bonded particle board produced from African Balsam tree (Populous Balsamifera) and Periwinkle shell residues. Results Eng. 2020; 6, 1-12.

[4] CC Ikeagwuani, DC Nwonu, DA Obetule, MU Omeje and T Festus. Potential of bamboo stem ash as supplementary cementitious material in concrete production. Int. J. Eng. Res. 2019; 8, 75-80.

[5] M Kasaniya, MDA Thomas and EG Moffatt. Pozzolanic reactivity of natural pozzolans, ground glasses and coal bottom ashes and implication of their incorporation on the chloride permeability of concrete. Cem. Concr. Res. 2021; 139, 1-12.

[6] SO Odeyemi, MA Anifowose, R Abdulwahab and WO Oduoye. Mechanical properties of highperformance concrete with guinea corn husk ash as additive. LAUTECH J. Civ. Environ. Stud. 2020; 5, 139-54.

[7] AT Muhammad, A Abdulaziz, M Noridah, OM Md Azree, ZM Muhamad and AI Muhamad. Effect of combining Palm Oil Fuel Ash (POFA) and Rice Husk Ash (RHA) as partial cement replacement to the compressive strength of concrete. Int. J. Integr. Eng. 2018; 10, 61-7.

[8] OJ Oyedepo, LM Olanitori and EO Olukanni. Investigation of palm kernel shell as partial replacement for aggregate in asphaltic concrete. Malaysian J. Civ. Eng. 2015; 27, 223-34.

[9] BS EN 197-1:2011 Cement. Composition, specifications and conformity criteria for common cements. British Standards Institution, London, 2011.

[10] S Karthik, PRM Rao and PO Awoyera. Strength properties of bamboo and steel reinforced concrete containing manufactured sand and mineral admixtures. J. King Saud Univ. Eng. Sci. 2017; 29, 400-6.

[11] GD Okwadha. Partial replacement of cement by plant solid waste ash in concrete production. $J$. Mech. Civ. Eng. 2016; 13, 35-40.

[12] DC Ugwuanyi and PN Onuamah. Suitability of agricultural by-products in Nigeria as partial replacement to cement in infrastructural projects: A review. GSJ. 2018; 6, 368-77.

[13] AA Raheem and EO Ibiwoye. A study of neem seed husk ash as partial replacement in concrete. Int. J. Sustain. Constr. Eng. Technol. 2018; 9, 55-64.

[14] DA Opeyemi, MP Otuaga and V Oluwasegunfunmi. Synergic effect of maize straw ash and rice husk ash on strength properties of sandcrete. Eur. J. Eng. Technol. 2013; 1, 32-9.

[15] T Qi, H Wang, G Feng, X Du, Z Wang and S Zhang. Effects of corn stalk fly ash (CSFA) on the mechanical and deformation properties of cemented coal gangue backfill. Hindawi Adv. Mater. Sci. Eng. 2020; $2020,1-14$.

[16] BS Thomas, S Kumar and HS Arel. Sustainable concrete containing palm oil fuel ash as a supplementary cementitious material: A review. Renew. Sustain. Energy Rev. 2017; 80, 550-61.

[17] W Sanawung, T Cheewaket, W Tangchirapat and C Jaturapitakkul. Influence of palm oil fuel ash and W/B ratios on compressive strength, water permeability, and chloride resistance of concrete. Hindawi Adv. Mater. Sci. Eng. 2017; 2017, 8.

[18] J Pone, A Ash, J Kamau and F Hyndman. Palm oil fuel ash as a cement replacement in concrete. Mod. Approaches Mater. Sci. 2018; 1, 4-8.

[19] NIS 444-1. Composition, specification and conformity criteria for common cements. Standards Organisation of Nigeria, Federal Capital Territory, 2003, p.13.

[20] BS EN 12620:2002+A1:2008. Specification for aggregates from natural sources for concrete. 
British Standards, London, 2008.

[21] AM Neville. Properties of Concrete, $5^{\text {th }}$ ed. Pearson Education Ltd., London, 2011.

[22] MS Shetty. Concrete Technology Theory and Practice. S. Chand and Company Ltd., New-Delhi, India, 2008.

[23] JE Bowles. Foundation Analysis and Design. The McGraw-Hill Companies, Inc., New York, 1996.

[24] T Mehmannavaz, M Ismail, S Radin Sumadi, MA Rafique Bhutta, M Samadi and SM Sajjadi. Binary effect of fly ash and palm oil fuel ash on heat of hydration aerated concrete. Sci. World J. 2014; 2014, 6 .

[25] BS EN 206:2013+A1:2016. Concrete. Specification, performance, production and conformity. 2016.

[26] DA Adesanya and AA Raheem. Development of corn cob ash blended cement. Constr. Build. Mater. 2009; 23, 347-52.

[27] K Voit, O Zeman, I Janotka, R Adamcova and K Bergmeister. High-durability concrete using ecofriendly slag-pozzolanic cements and recycled aggregate. Appl. Sci. 2020; 10, 1-21.

[28] AH Vakili, MR Selamat and H Moayedi. Effects of using pozzolan and portland cement in the treatment of dispersive clay. Sci. World J. 2013; 2013, 1-12.

[29] BS EN 12390-3:2009. Testing hardened concrete - compressive strength of test specimens. British Standards, London. 2009.

[30] BS 812-103.1:1985. Methods for determination of particle size distribution-section 103.1 sieve tests. British Standards, London, 1989.

[31] OO Ogunleye, O Adio, TO Salawudeen and OO Agbede. Optimal adsorption parameters of banana (Musa paradisiaca) stalk based activated carbon for removal of lead (II) from aqueous solution. Int. J. Sci. Eng. Res. 2015; 6, 499-507. 